\title{
EFEK BERSEPEDA TERHADAP PROSES PENUAAN PADA LANJUT USIA: LITERATUR REVIEW
}

\section{THE EFFECT OF CYCLING ON THE AGING PROCESS IN THE ELDERLY: LITERATURE REVIEW}

\author{
Upik Rahmi1 $^{*}$, Nova Sylviana ${ }^{2}$, Hanna Goenawan ${ }^{3}$, Setiawan $^{4}$ \\ 1Program Studi Kedokteran, Fakultas Kedokteran, Universitas Padjadjaran , Jatinangor 45363. \\ Indonesia \\ 2,3,4Divisi Fisiologi, Departemen Ilmu Biomedis, Fakultas Kedokteran, Universitas Padjadjaran, \\ Jatinangor 45363, Indonesia
}

*Corresponding Author: Upik Rahmi, upikrahmi@upi.edu

Received: 2021-06-01; Revised: 2021-07-08; Accepted: 2021-07-09

\begin{abstract}
Abstrak
Tujuan Literatur review ini untuk menganalisis artikel efek aktifitas fisik bersepeda (cycling) terhadap proses penuaan (aging prosess). Metode dengan menggunakan Databased PubMed, MEDLINE, sciencedirect dan google scholar. Pencarian artikel menggunakan kata kunci: Elderly, physical activity, cycling, aging process. Artikel maupun kajian yang terbit dalam kurun waktu 15 tahun terakhir pada jurnal internasional berbahasa inggris yang dapat diakses. Hasil review 14 artikel tersebut terlihat adanya pengaruh intervensi bersepeda baik indoor maupun outdoor terhadap proses terjadinya penuaan (kognitif, cardiovascular, muskuloskeletal, imunologi dan endokrin). Proses penuaan merupakan penurunan kapasitas fungsional, baik pada tingkat selular maupun pada tingkat organ dan hilangnya kemampuan memelihara homeostasis tubuh, disfungsi sistem organ dan perubahan fisiologis tubuh. Kesimpulan; Aktifitas fisik mencegah proses penuaan (process aging) baik pria maupun wanita secara fisiologis (kognitif, cardiovascular, endokrin, muskulosekeletal dan imunologi), sehingga dengan bersepeda akan meningkatkan fungsi tubuh dan kualitas hidup menjadi lebih baik pada usia tua. Keterbatasan pada review hanya studi yang diterbitkan dalam 15 tahun terakhir, kekurangan penilaian efek ukuran. Selain itu, metode penelitian tidak dilihat apakah itu metode eksperimen atau non eksperimen..
\end{abstract}

Kata Kunci: lanjut usia, bersepeda, kognitif, endokrine, imunologi, muskuloskeletal

\begin{abstract}
Purposes this literature review is to analyze the effect of cycling physical activity on the aging process. The method using Databased PubMed, MEDLINE, ScienceDirect, and google scholar. Search articles using keywords: Elderly, physical activity, cycling, the aging process. Articles and studies published in the last 15 years in accessible English-language international journals. The results of the analysis of the 14 articles show that there is an effect of cycling interventions both indoor and outdoor on the aging process (cognitive, cardiovascular, musculoskeletal, immunological, and endocrine). The aging process is a decrease in functional capacity, both at the cellular level and at the organ level, and the loss of the ability to maintain body homeostasis, organ system dysfunction, and physiological changes in the body. Conclusion; Physical activity can slow down the aging process for both men and women, in the analysis of this study it has been proven that physical activity by cycling (cycling) can slow down the aging process physiologically (cognitive, cardiovascular, endocrine, musculoskeletal, and immunological), so cycling will improve body functions so that quality of life improves in old age. Limitations of


Journal of Sport Education (JOPE), 4 (1) 2021 - 65

${\text { Upik Rahmi }{ }^{*} \text {, Nova Sylviana }}^{2}$, Hanna Goenawan ${ }^{3}$, Setiawan ${ }^{4}$

reviewing only studies published in the last 15 years, lack of assessment of effect sizes. In addition, the research method is not seen whether it is an experimental or non-experimental method.

Keywords: elderly, cycling, cognitive, endocrine, imunology, musculoskeletal.

How To Cite: Rahmi, U., Sylviana, N., Goenawan , H., Setiawan. (2021). Efek bersepeda terhadap proses penuaan pada lanjut usia: literatur review. Journal of Sport Education (JOPE), 4(1), 64-76. doi:http://dx.doi.org/10.31258/jope.4.1.64-76

Journal Of Sport Education (JOPE) is an open access article under the CC-BY-SA 4.0

\section{PENDAHULUAN}

Populasi di dunia mengalami penuaan dengan cepat (He, Goodkind, \& Kowal, 2016) sehingga dapat dikatakan populasi lanjut usia merupakan fenomena global. Penuaan merupakan proses adaptasi yang panjang karena peningkatan harapan hidup (FernandezEgea et al., 2013). Umur panjang yang sehat meningkatkan kesejahteraan manusia (Bloom, Canning, \& Lubet, 2015).

Penuaan ditandai dengan penurunan fisiologis tubuh karena penuaan berubah seiring bertambahnya usia, namun, penelitian terbaru menunjukkan (Pan, Lai, Tsai, Wu, \& Ho, 2012) setiap individu menua pada tingkat yang berbeda dan terdapat heterogenitas dalam respon fisiologis. Dalam studi ini, penuaan yang dimaksud adalah "Healthy aging", untuk membedakan suatu proses penuaan "sukses dan sehat"” (Hammar \& Östgren, 2013).

Penuaan yang sehat (Hammar \& Östgren, 2013) adalah penuaan yang tidak memiliki penyakit, tidak mengalami cacat terkait penyakit, kapasitas fungsi kognitif dan fisik yang baik dan keterlibatan aktif dalam kehidupan. Meskipun penurunan fungsi tubuh terjadi akibat penyakit maupun kecacatan pada dewasa akhir namun hal tersebut dapat dicegah di usia tua (Erickson \& Kramer, 2009). Penurunan fungsi tubuh terkait usia dan homeostasis memiliki implikasi klinis dalam memahami penyakit pada pasien yang lebih tua (Navaratnarajah \& Jackson, 2013).

Salah satu aktifitas untuk mencegah penuan dengan aktifitas fisik, aktivitas fisik yang teratur merupakan salah satu komponen terpenting dari penuaan yang sehat termasuk aerobik exercise (Eckstrom, Neukam, Kalin, \& Wright, 2020). Aktifitas fisik merupakan intervensi kesehatan yang sederhana, murah dan efektif bagi kebanyakan individu (Rea, 2017).

Aerobik Exercise adalah olahraga meningkatkan detak jantung dan laju pernapasan seseorang dalam jangka waktu yang relatif lama. Sedangkan anaerobik exercise merupakan olah raga yang melibatkan aktivitas intens dalam waktu singkat (Erickson \& Kramer, 2009)(Yaffe et al., 2009). Aerobik Exercise (jalan, jogging, lari, bersepeda, dan renang dapat meningkatkan fungsi kekebalan dengan peningkatan jumlah sel-T dan sel-B secara signifikan (Turner \& Brum, 2017; Shaw, Merien, Braakhuis, \& Dulson, 2018; Molanouri Shamsi, Najedi, Hassan, Isanejad, \& Mahdavi, 2017).

Aerobik Exercise juga meningkatkan fungsi kardiovaskular dengan peningkatan stroke volume dan curah jantung (Sarikaya, Dursun, Taylan Deveden, \& Pinar, 2017; Wallace et al., 2018). Hal ini juga menunjukkan bahwa peningkatan aliran darah melalui arteri perifer selama latihan akan meningkatkan homeostasis vaskular dengan menurunkan oksigen reaktif dan meningkatkan ketersediaan oksida nitrat di endotel (Durand \& Gutterman, 2014). Selain itu, senam aerobik dapat meningkatkan kapasitas anti oksidan tubuh dengan cara mengurangi pembentukan radikal bebas dan meningkatkan aktivitas superoksida dismutase (SOD) dan rasio malondialdehida (MDA) (Danese et al., 2017).

Aerobic exercise tidak hanya dapat mendorong penghapusan radikal bebas, tetapi juga memperlambat pengurangan anti-oksidan yang menyebabkan penuaan (Gardner et al., 2018), 
keseimbangan antara sistem oksidasi dan anti-oksidasi (Nehra, Bhardwaj, Bansal, \& Saraswat, 2017), mengurangi kecemasan (M. D. Hill, Gibson, Wagerman, Flores, \& Kelly, 2019), depresi, dan dan meningkatkan fungsi kognisi (Chacko et al., 2020; Tascón, Boccia, Piccardi, \& Cimadevilla, 2017) memperbaiki DNA yang rusak untuk memperpanjang umur. Perbaikan gen komplementer silang 1 (ERCC1) yang merupakan enzim perbaikan DNA yang rusak (Ji et al., 2019). Meningkatkan kadar Sirtuin-1 (SIRT1), Sirtuin-3 (SIRT3), Sirtuin-6 (SIRT6), Peroxisome proliferator-activated reseptor gamma coactivator 1-alpha (PGC1- $\alpha$ ) merupakan protein pada proses penuaan biologis (Hooshmand-Moghadam et al., 2020).

Aerobic exercise juga menghambat korteks somatosensori primer (S1) (Yamazaki et al., 2020) mempengaruhi sistem Serotonin (5-HT) dan brain derived neurotrophic factor (BDNF) (BDNF-5-HT), meningkatkan fungsi kognitif dan melindungi otak (Pietrelli et al., 2018)(Griffin et al., 2011a) dengan insulin-like growth factor-1 (IGF-1) (Whiteman et al., 2014) meningkatkan saliva alpha amylase pada fungsi kognitif (Weiss, Venezia, \& Smith, 2019).

Jenis aerobik exercise yang telah banyak diteliti adalah menari/dancing (RodriguesKrause et al., 2018), yoga, senam terhadap fungsi jantung (Patil, Patil, Aithala, \& Das, 2017) dan jalan kaki terhadap fungsi kognitif (Raichlen et al., 2020; Pothier et al., 2018; Haynes et al., 2020), treadmill dan water-swimming. Namun penelitian tentang bersepeda (cycling) terhadap penuaan masih sedikit. Oleh karena itu, Study review ini bertujuan untuk melihat pengaruh cycling terhadap Proses penuaan (proceess aging) pada lanjut usia.

\section{METODE}

Untuk pencarian artikel dengan menggunakan Databased PubMed, MEDLINE, sciencedirect dan google scholar. Pencarian artikel menggunakan kata kunci berikut: Elderly, physical activity, cycling, aging process. (Portney, 2020). Artikel maupun kajian yang terbit dalam kurun waktu 15 tahun terakhir pada jurnal internasional berbahasa inggris. Artikelartikel ini, disusun dalam tabel, setelah itu, proses seleksi kedua dilakukan, di mana artikel yang tersisa ditinjau terhadap kriteria inklus (original artikel, artikel tentang cycling, aging procees, Tahun 2006-2021, berbahasa inggris, lanjut usia). Kriteria ekslusi (Sebelum Tahun 2006, intervensi bukan cycling, bukan berbahasa inggris).

Di seleksi pertama, abstrak untuk setiap subkelompok dianalisis. Abstrak studi tidak menganalisis cycling dan aging proses. Dari 4813 artikel yang ditinjau dari 4 data based yaitu PubMed, MEDLINE, sciencedirect dan google scholar. Ditemukan 67 artikel duplikat. Artikel yang dikeluarkan karena tidak sesuai judul 2913, tidak sesuai dengan abstrak 1819 dan yang tersisa adalah 14 artikel yang sesuai dengan tujuan.

\section{HASIL}

Hasil screening didapatkan 14 artikel tentang pengaruh bersepeda terhadap proses penuaan pada lanjut usia (Hötting, Holzschneider, Stenzel, Wolbers, \& Röder, 2013), (Chu, Alderman, Wei, \& Chang, 2015), (Elliott et al., 2017), (Frost et al., 2020), (Griffin et al., 2011a), (Hötting et al., 2012a), (Hough, Corney, Kouris, \& Gleeson, 2013); (Hyodo et al., 2016); (L. Leyland \& Spencer, 2019); (Skriver et al., 2014); (Torbeyns et al., 2016); (Vingren et al., 2016); (Weiss et al., 2019); (Ross et al., 2018).

Pengaruh bersepeda terhadap peningkatn fungsi kognitif (memory, fungsi kognitif, fungsi eksekutif) (Beelen et al., 2014) (Chu, Chen, Hung, Wang, \& Chang, 2015) (L. A. Leyland, Spencer, Beale, Jones, \& van Reekum, 2019) (Torbeyns et al., 2016). Peran GDF11 rendah dalam penuaan sehat (Elliott et al., 2017), peningkatan memory (Frost et al., 2020) (Hötting et al., 2012b) meningkatnya konsentrasi BDNF (Griffin et al., 2011b) (Skriver et al., 2014) peningkatan kortisol dan testosteron (Leyland et al., 2019; Weiss et al., 2019).

Peningkatan alfa-amilase saliva dan sel $\mathrm{T}+(\mathrm{CD} 28 \mathrm{null})$ lebih responsif (Ross et al., 2018). 
Journal of Sport Education (JOPE), 4 (1) 2021 - 67

Upik Rahmi $^{1 *}$, Nova Sylviana ${ }^{2}$, Hanna Goenawan ${ }^{3}$, Setiawan ${ }^{4}$

Tabel 1. Analisis studi efek bersepeda terhadap proses penuaan

\begin{tabular}{|c|c|c|c|c|c|c|}
\hline No & Artikel & Tujuan & Fisologis & $\mathbf{N}$ & Intervensi & Hasil \\
\hline 1 & $\begin{array}{l}\text { Kirsten } \\
\text { Hötting; } \\
2013\end{array}$ & $\begin{array}{l}\text { Untuk melihat efek } \\
\text { kognitif (spasil training vs } \\
\text { persepsi kontrol training) }\end{array}$ & $\begin{array}{c}\text { Fungsi } \\
\text { kognitif }\end{array}$ & 33 & $\begin{array}{l}\text { Cycling } \\
\text { indoor }\end{array}$ & $\begin{array}{l}\text { Perubahan } \\
\text { signifikan pada } \\
\text { kelompok latihan } \\
\text { kognitif (spasial) }\end{array}$ \\
\hline 2 & $\begin{array}{l}\text { Chien- } \\
\text { Heng } \\
\text { Chu; } \\
2015\end{array}$ & $\begin{array}{l}\text { Untuk melihat exercise } \\
\text { akut pada fungsi kognitif } \\
\text { dan peran modulatori } \\
\text { fitnes antara exercise dan } \\
\text { kognitif }\end{array}$ & $\begin{array}{l}\text { Fungsi } \\
\text { Kognitif }\end{array}$ & 24 & $\begin{array}{l}\text { Cycling } \\
\text { indoor }\end{array}$ & $\begin{array}{l}\text { Exercise akut dapat } \\
\text { meningkatkan } \\
\text { kinerja kognitif }\end{array}$ \\
\hline 3 & $\begin{array}{l}\text { Bradley } \\
\text { T; } 2017\end{array}$ & $\begin{array}{l}\text { Membandingkan tingkat } \\
\text { istirahat myostatin plasma } \\
\text { dan peptida yang } \\
\text { berinteraksi dengan } \\
\text { myostatin antara SED } \\
\text { seumur hidup dan } \\
\text { kelompok kontrol positif } \\
\text { pria yang menua yang } \\
\text { berolahraga seumur hidup } \\
\text { (LEX\} }\end{array}$ & Muskulo & 62 & $\begin{array}{l}\text { Cycling } \\
\text { indoor }\end{array}$ & $\begin{array}{l}\text { SED menunjukkan } \\
\text { konsentrasi total } \\
\text { myostatin dan } \\
\text { follistatin serum } \\
\text { yang lebih besar, } \\
\text { dan konsentrasi } \\
\text { GDF11 yang lebih } \\
\text { rendah }\end{array}$ \\
\hline 4 & $\begin{array}{l}\text { Natalie } \\
\text { Frost; } \\
2020\end{array}$ & $\begin{array}{l}\text { Efek dari intervensi } \\
\text { latihan yang secara } \\
\text { sistematis pada fungsi } \\
\text { eksekutif. }\end{array}$ & $\begin{array}{l}\text { Fungsi } \\
\text { Kognitif }\end{array}$ & $\begin{array}{c}64 \\
\text { wanita }\end{array}$ & $\begin{array}{l}\text { Cycling } \\
\text { indoor }\end{array}$ & $\begin{array}{l}\text { Hubungan yang } \\
\text { signifikan antara } \\
\text { perubahan dalam } \\
\text { kebugaran } \\
\text { kardiorespirasi dan } \\
\text { kedua Updating / } \\
\text { Working Memory } \\
\text { dan Verbal } \\
\text { Generativity }\end{array}$ \\
\hline 5 & $\begin{array}{l}\text { Éadaoin } \\
\text { W. } \\
\text { Griffin; } \\
2011\end{array}$ & $\begin{array}{l}\text { Efek latihan akut pada } \\
\text { kinerja tugas pencocokan } \\
\text { nama-wajah, hipokampus } \\
\text { dan struktur terkait dari } \\
\text { lobus temporal medial, } \\
\text { dan tugas warna kata } \\
\text { Stroop, dan menilai } \\
\text { konsentrasi sirkulasi } \\
\text { BDNF dan IGF -1 }\end{array}$ & $\begin{array}{l}\text { Fungsi } \\
\text { Kognitif }\end{array}$ & 22 & $\begin{array}{l}\text { Cycling } \\
\text { indoor }\end{array}$ & $\begin{array}{l}\text { Meningkatkan } \\
\text { kinerja dalam } \\
\text { pembelajaran } \\
\text { hipokampus dan } \\
\text { mengubah respons } \\
\text { BDNF serum }\end{array}$ \\
\hline 6 & $\begin{array}{l}\text { Kirsten } \\
\text { Hötting; } \\
2012\end{array}$ & $\begin{array}{l}\text { Untuk menguji aktivitas } \\
\text { fisik meningkatkan fungsi } \\
\text { kognitif pada orang } \\
\text { dewasa paruh baya yang } \\
\text { sebelumnya tidak banyak } \\
\text { bergerak, sehat }\end{array}$ & $\begin{array}{l}\text { Fungsi } \\
\text { kognitif }\end{array}$ & 68 & $\begin{array}{l}\text { Cycling } \\
\text { indoor }\end{array}$ & $\begin{array}{l}\text { Peningkatan } \\
\text { memori episodik } \\
\text { berkorelasi positif } \\
\text { dengan } \\
\text { peningkatan } \\
\text { kebugaran } \\
\text { kardiovaskular. }\end{array}$ \\
\hline 7 & $\begin{array}{l}\text { John } \\
\text { Hough; } \\
2013\end{array}$ & $\begin{array}{l}\text { Respon kortisol dan } \\
\text { testosteron saliva untuk } \\
\text { dua, intensitas tinggi yang } \\
\text { berbeda, siklus } \sim 30 \text { menit } \\
\text { dipisahkan oleh istirahat } 2 \\
\text { jam sebelum dan setelah } \\
\text { periode pelatihan intensif } \\
11 \text { hari. }\end{array}$ & Endokrin & 119 & $\begin{array}{l}\text { Cycling } \\
\text { indoor }\end{array}$ & $\begin{array}{l}\text { Perubahan kortisol } \\
\text { dan testosteron } \\
\text { saliva }\end{array}$ \\
\hline
\end{tabular}


Journal of Sport Education (JOPE), 4 (1) 2021 - 68

Upik Rahmi ${ }^{*}$, Nova Sylviana ${ }^{2}$, Hanna Goenawan ${ }^{3}$, Setiawan ${ }^{4}$

Lanjutan Tabel 1. Analisis studi efek bersepeda terhadap proses penuaan

\begin{tabular}{|c|c|c|c|c|c|c|}
\hline No & Artikel & Tujuan & Fisologis & $\mathbf{N}=$ & Intervensi & Hasil \\
\hline 8 & $\begin{array}{l}\text { Kazuki } \\
\text { Hyodo; } \\
2015\end{array}$ & $\begin{array}{l}\text { untuk mengungkapkan } \\
\text { hubungan antara } \\
\text { kebugaran aerobik, fungsi } \\
\text { kognitif, dan lateralisasi } \\
\text { frontal. }\end{array}$ & $\begin{array}{c}\text { Fungsi } \\
\text { Kognitif }\end{array}$ & $\begin{array}{c}60 \\
\text { pria }\end{array}$ & $\begin{array}{l}\text { Cycling } \\
\text { indoor }\end{array}$ & $\begin{array}{l}\text { VT yang lebih tinggi } \\
\text { dan aktivasi DLPFC } \\
\text { yang lebih miring } \\
\text { ke kiri }\end{array}$ \\
\hline 9 & $\begin{array}{l}\text { Louise- } \\
\text { Ann } \\
\text { Leyland; } \\
2019\end{array}$ & $\begin{array}{l}\text { Untuk menyelidiki } \\
\text { pengaruh intervensi } \\
\text { bersepeda luar ruangan } \\
\text { pada fungsi kognitif dan } \\
\text { kesehatan mental dan } \\
\text { kesejahteraan pada orang } \\
\text { dewasa yang lebih tua }\end{array}$ & Fungsi kognitif & 100 & $\begin{array}{l}\text { Cycling } \\
\text { indoor }\end{array}$ & $\begin{array}{l}\text { Peningkatan fungsi } \\
\text { eksekutif }\end{array}$ \\
\hline 10 & $\begin{array}{l}\text { Kasper } \\
\text { Skriver; } \\
2013\end{array}$ & $\begin{array}{l}\text { Mengeksplorasi } \\
\text { biomarker terkait } \\
\text { olahraga potensial dan } \\
\text { hubungannya dengan } \\
\text { ukuran memori motorik } \\
\text { dan akuisisi keterampilan. }\end{array}$ & Kognitif & 31 & $\begin{array}{l}\text { Cycling } \\
\text { indoor }\end{array}$ & $\begin{array}{l}\text { Peningkatan } \\
\text { konsentrasi } \\
\text { biomarker }\end{array}$ \\
\hline 11 & $\begin{array}{l}\text { Tine } \\
\text { Torbeyns; } \\
2016\end{array}$ & $\begin{array}{l}\text { Efek bersepeda pada } 30 \% \\
\text { Wmax pada mengetik, } \\
\text { kinerja kognitif dan } \\
\text { aktivitas otak. }\end{array}$ & Fungsi Kogntif & 23 & $\begin{array}{l}\text { Cycling } \\
\text { indoor }\end{array}$ & $\begin{array}{l}\text { Efek positif pada } \\
\text { kecepatan respons } \\
\text { di seluruh tugas }\end{array}$ \\
\hline 12 & $\begin{array}{l}\text { Jakob L. } \\
\text { Vingre, } \\
2015\end{array}$ & $\begin{array}{l}\text { Respons endokrin akut } \\
\text { terhadap bersepeda jalan } \\
\text { raya sepanjang } 164 \mathrm{~km} \text { di } \\
\text { lingkungan yang panas }\end{array}$ & Endokrin & 34 & $\begin{array}{l}\text { Cycling } \\
\text { Outdoor }\end{array}$ & $\begin{array}{l}\text { Perubahan akut } \\
\text { pada konsentrasi } \\
\text { hormon yang } \\
\text { bersirkulasi, } \\
\text { dengan } \\
\text { peningkatan GH } \\
\text { dan kortisol }\end{array}$ \\
\hline 13 & $\begin{array}{l}\text { Lauren R. } \\
\text { Weiss; } \\
2019\end{array}$ & $\begin{array}{l}\text { Efek latihan bersepeda } \\
\text { intensitas tinggi } \\
\text { berdasarkan aktivitas } \\
\text { selama } 20 \text { menit pada } \\
\text { tingkat alfa-amilase saliva } \\
\text { pada orang dewasa muda } \\
\text { yang sehat }\end{array}$ & $\begin{array}{l}\text { Fungsi } \\
\text { Kognitif }\end{array}$ & 32 & $\begin{array}{l}\text { Cycling } \\
\text { indoor }\end{array}$ & $\begin{array}{l}\text { Peningkatan alfa- } \\
\text { amilase saliva kira- } \\
\text { kira enam kali lebih } \\
\text { tinggi. }\end{array}$ \\
\hline 14 & $\begin{array}{l}\text { Mark } \\
\text { Ross; } \\
2018\end{array}$ & $\begin{array}{l}\text { Untuk melihat } \\
\text { responsif sel CD28null + } \\
\text { TANG terhadap latihan }\end{array}$ & Cardiovascular & $\begin{array}{c}19 \\
\text { pria }\end{array}$ & $\begin{array}{l}\text { Cycling } \\
\text { indoor }\end{array}$ & $\begin{array}{l}\text { Meningkatkan } \\
\text { jumlah sel T yang } \\
\text { signifikan pada } \\
\text { laki-laki muda } \\
\text { maupun tua. }\end{array}$ \\
\hline
\end{tabular}

\section{PEMBAHASAN}

Hasil analisis studi 14 artikel tersebut terlihat adanya pengaruh intervensi bersepeda terhadap proses terjadinya penuaan. Proses penuaan merupakan penurunan kapasitas fungsional, baik pada tingkat selular maupun pada tingkat organ dan hilangnya kemampuan memelihara homeostasis tubuh, disfungsi sistem organ dan perubahan fisiologis tubuh (Navaratnarajah \& Jackson, 2013).

Bersepeda mengurangi penuaan pada fisiologis tubuh dengan meningkatkan kesehatan fisik, mental dan sosial (Buehler, Pucher, \& Bauman, 2020) meningkatkan imunitas (Palmowski, Reichel, Boßlau, \& Krüger, 2020) penurunan respons kortisol saliva dan testosteron pada keadaan stress, keseimbangan katabolik/anabolik (Hough et al., 2013) 
meningkatkan growth hormon dan kortisol (Vingren et al., 2016) enzim intrasel plasma aspartat aminotransferase, alanine aminotransferase, dan alkali fosfatase (Maass et al., 2016), mengurangi konsentrasi Endotelium-1 plasma pada manusia yang lebih tua yang memiliki efek pada sistem kardiovaskular (pencegahan hipertensi dan/atau aterosklerosis) (Maeda et al., 2003) meningkatkan fungsi kognitif, fungsi eksekutif, memory, fungsi spatial (Leyland et al., 2019; Weiss et al., 2019).

Peningkatan kesehatan kognitif dengan bersepeda menunjukkan bahwa fungsi kognitif dan integritas otak dapat dipertahankan, atau bahkan ditingkatkan, melalui peningkatan frekuensi dan durasi olahraga sedang hingga berat (Erickson \& Kramer, 2009) (Yaffe et al., 2009) karena dapat mengurangi terjadinya gangguan neurodegeneratif terkait usia, seperti penyakit Alzheimer dan demensia vaskular untuk mencapai kualitas hidup yang baik pada dewasa muda hingga dewasa akhir (Rodrigues \& Ballesteros, 2007; Karp et al., 2006).

Penilaian fungsi kognitif termasuk fungsi eksekutif dapat diukur dengan menggunakan Verbal Fluency, Plus-minus task., Letter updating task, Stroop task, Stop-it task, Eriksen flanker task, memory diukur dengan menggunakan (Consortium to Establish a Registry for Alzheimer's Disease (CERAD) dan spatial function task diukur menggunakan Mazes and mental rotation task immediate and delayed recall) (Miyake et al., 2000; L. A. Leyland et al., 2019). Pada penelitian (Torbeyns et al., 2016) fungsi eksekutif diukur dengan menggunakan Rey auditory verbal learning test digunakan untuk menilai memori jangkat pendek. Penilaian fungsi kognitif selain fungsi ekseskutif dan memory memory juga ada processing speed yang diukur dengan menggunakan Fuld Object Memory Evaluation (FOME) (Silva, Lott, Wickrama, Mota, \& Welk, 2011). Selain bersepeda dengan berjalan kaki juga dapat meningkatkan fungsi kognitif, eksekutif dan memory (Raichlen et al., 2020; Pothier et al., 2018; Haynes et al., 2020)

Fungsi kognitif juga dapat dinilai melalui mekanisme neurobiologis, yang dimediasi oleh faktor pertumbuhan seperti $B D N F$, IGF-I, dan VEGF (Woost et al., 2018) dapat juga diukur menggunakan alfa-amilase saliva.

Bersepeda memiliki efek yang positif pada sel T terutama faktor endotel progenitor cell yang berperan untuk meningatkan fungsi endotel untuk mencegah penyakit kardiovaskular dengan bersepeda cycling meningkatkan jumlah sel TANG beredar dan sel-sel lebih responsif terhadap olahraga daripada sel CD28 + TANG, meningkatkan MBF stres pada pasien pasca infark, dengan penurunan terbalik sitokin angiogenik yang bersirkulasi, adanya pola modifikasi yang berbeda untuk EPC terkait peningkatan kapasitas latihan. Didukung oleh penelitian (Cesari et al., 2009) dengan tiga bulan aktivitas fisik meningkatkan secara signifikan jumlah EPC.

EPC bekerja dalam angiogenesis melalui perbaikan vaskular dan diaktivasi oleh SDF-1 dan VEGF. Kadar EPC yang bersirkulasi rendah sangat terkait dengan peningkatan risiko penyakit kardiovaskular dan gangguan fungsi endotel (J. M. Hill et al., 2003) karena EPC berperan untuk neovaskularisasi jaringan iskemik (Vasa et al., 2001). Endotel vaskular memiliki peran dalam respon imun, hemostasis, dan regulasi tekanan darah (Endemann \& Schiffrin, 2004). Peningkatan fungsi Cardivascular respirasi dengan bersepeda dan menari (Rodrigues-Krause, Farinha, Krause, \& Reischak-Oliveira, 2016) sama-sama meningkatkan V02 peak dan kebugaran.

Pengaruh bersepada pada endokrin terlihat konsentrasi sirkulasi testosteron berkurang sedangkan konsentrasi hormon pertumbuhan (GH) dan kortisol meningat (Kraemer et al., 2008). Penelitian ini menemukan peningkatan lebih dari $70 \%$ konsentrasi kortisol yang bersirkulasi, konsentrasi tinggi kortisol dapat secara substansial mempengaruhi konsentrasi testosteron (Gates, Fiatarone Singh, Sachdev, \& Valenzuela, 2013) dengan demikian, peningkatan besar kortisol bertanggung jawab untuk pengurangan akut testosteron. 
Bersepeda dapat mempengaruhi proses fisiologis penuaan, baik itu bersepeda indoor maupun outdor. Orang yang aktif bersepeda akan meningkatkan kesehatan cardiopulmonal dan bisa mempengeruhi kepada kualitas hidup yang lebih baik pada usia tua.

\section{SIMPULAN}

Bersepada (Cycling) dapat memperlambat proses penuan baik pria maupun wanita, pada analisis studi ini telah terbukti aktifitas fisik dengan bersepeda (cycling) dapat memperlambat proses penuan secara fisiologis (kognitif, cardiovascular, endokrin, muskulosekeletal dan imunologi). Review ini memiliki beberapa keterbatasan: diantaranya studi yang diterbitkan dalam 15 tahun terakhir. Selain itu, penilaian metode penelitian tidak dianalisis apakah itu metode eksperimen atau non eksperimen. Tinjauan di masa mendatang harus mencakup penilaian yang lebih rinci tentang kualitas dan termasuk elemen desain yang lebih fokus ke RCT, Spesifik penilaian fungsi fisiologis tubuh dan hasil penelitian.

\section{DAFTAR PUSTAKA}

Beelen, R., Raaschou-Nielsen, O., Stafoggia, M., Andersen, Z. J., Weinmayr, G., Hoffmann, B., ... Hoek, G. (2014). Effects of long-term exposure to air pollution on natural-cause mortality: an analysis of 22 European cohorts within the multicentre ESCAPE project. Lancet (London, England), 383(9919), 785-795. https://doi.org/10.1016/S01406736(13)62158-3

Bloom, D. E., Canning, D., \& Lubet, A. (2015). Global Population Aging: Facts, Challenges, Solutions \& Perspectives.

Buehler, R., Pucher, J., \& Bauman, A. (2020). Physical activity from walking and cycling for daily travel in the United States, 2001-2017: Demographic, socioeconomic, and geographic variation. Journal of Transport and Health, 16(January), 100811. https://doi.org/10.1016/j.jth.2019.100811

Cesari, F., Sofi, F., Corsani, I., Pucci, N., Caporale, R., Abbate, R., ... Casini, A. (2009). [22] Effect of a Personalized Physical Activity Programme on Weight Reduction and Endothelial Progenitor Cells in Overweight Subjects. Nutrition, Metabolism and Cardiovascular Diseases, 19, S6. https://doi.org/10.1016/s0939-4753(09)70023-7

Chacko, S. C., Quinzi, F., De Fano, A., Bianco, V., Mussini, E., Berchicci, M., ... Di Russo, F. (2020). A single bout of vigorous-intensity aerobic exercise affects reactive, but not proactive cognitive brain functions. International Journal of Psychophysiology, 147, 233-243. https://doi.org/10.1016/j.ijpsycho.2019.12.003

Chu, C.-H., Alderman, B. L., Wei, G.-X., \& Chang, Y.-K. (2015). Effects of acute aerobic exercise on motor response inhibition: An ERP study using the stop-signal task. Journal of Sport and Health Science, 4(1), 73-81. https://doi.org/https://doi.org/10.1016/j.jshs.2014.12.002

Chu, C.-H., Chen, A.-G., Hung, T.-M., Wang, C.-C., \& Chang, Y.-K. (2015). Exercise and fitness modulate cognitive function in older adults. Psychology and Aging, 30(4), 842-848. https://doi.org/10.1037/pag0000047 
Danese, E., Lippi, G., Sanchis-Gomar, F., Brocco, G., Rizzo, M., Banach, M., \& Montagnana, M. (2017). Physical Exercise and DNA Injury: Good or Evil? In Advances in Clinical Chemistry (1st ed., Vol. 81). https://doi.org/10.1016/bs.acc.2017.01.005

Durand, M. J., \& Gutterman, D. D. (2014). Exercise and vascular function: How much is too much? Canadian Journal of Physiology and Pharmacology, 92(7), 551-557. https://doi.org/10.1139/cjpp-2013-0486

Eckstrom, E., Neukam, S., Kalin, L., \& Wright, J. (2020). Physical Activity and Healthy Aging. Clinics in Geriatric Medicine, 36(4), 671-683. https://doi.org/10.1016/j.cger.2020.06.009

Elliott, B. T., Herbert, P., Sculthorpe, N., Grace, F. M., Stratton, D., \& Hayes, L. D. (2017). Lifelong exercise, but not short-term high-intensity interval training, increases GDF11, a marker of successful aging: a preliminary investigation. Physiological Reports, 5(13). https://doi.org/10.14814/phy2.13343

Endemann, D. H., \& Schiffrin, E. L. (2004). Endothelial dysfunction. Journal of the American Society of Nephrology, 15(8), 1983-1992. https://doi.org/10.1097/01.ASN.0000132474.50966.DA

Erickson, K. I., \& Kramer, A. F. (2009). Aerobic exercise effects on cognitive and neural plasticity in older adults. British Journal of Sports Medicine, 43(1), 22-24. https://doi.org/10.1136/bjsm.2008.052498

Fernandez-Egea, E., Scoriels, L., Theegala, S., Giro, M., Ozanne, S. E., Burling, K., \& Jones, P. B. (2013). Cannabis use is associated with increased CCL11 plasma levels in young healthy volunteers. Progress in Neuro-Psychopharmacology \& Biological Psychiatry, 46, 25-28. https://doi.org/10.1016/j.pnpbp.2013.06.011

Frost, N. J., Weinborn, M., Gignac, G. E., Rainey-Smith, S. R., Markovic, S., Gordon, N., ... Brown, B. M. (2020). A Randomized Controlled Trial of High-Intensity Exercise and Executive Functioning in Cognitively Normal Older Adults. American Journal of Geriatric Psychiatry. https://doi.org/10.1016/j.jagp.2020.06.015

Gardner, A. W., Montgomery, P. S., Zhao, Y. D., Ungvari, Z., Csiszar, A., \& Sonntag, W. E. (2018). Endothelial Cell Inflammation and Antioxidant Capacity are Associated With 6-Minute Walk Performance in Patients With Symptomatic Peripheral Artery Disease. Angiology, 69(5), 416-423. https://doi.org/10.1177/0003319717726934

Gates, N., Fiatarone Singh, M. A., Sachdev, P. S., \& Valenzuela, M. (2013). The effect of exercise training on cognitive function in older adults with mild cognitive impairment: a metaanalysis of randomized controlled trials. The American Journal of Geriatric Psychiatry: Official Journal of the American Association for Geriatric Psychiatry, 21(11), 1086-1097. https://doi.org/10.1016/j.jagp.2013.02.018

Griffin, É. W., Mullally, S., Foley, C., Warmington, S. A., O’Mara, S. M., \& Kelly, Á. M. (2011a). Aerobic exercise improves hippocampal function and increases BDNF in the serum of young adult males. Physiology and Behavior, 104(5), 934-941. https://doi.org/10.1016/j.physbeh.2011.06.005 
Griffin, É. W., Mullally, S., Foley, C., Warmington, S. A., O’Mara, S. M., \& Kelly, Á. M. (2011b). Aerobic exercise improves hippocampal function and increases BDNF in the serum of young adult males. Physiology \& Behavior, 104(5), 934-941. https://doi.org/https://doi.org/10.1016/j.physbeh.2011.06.005

Hammar, M., \& Östgren, C. J. (2013). Healthy aging and age-adjusted nutrition and physical fitness. Best Practice \& Research Clinical Obstetrics \& Gynaecology, 27(5), 741-752. https://doi.org/https://doi.org/10.1016/j.bpobgyn.2013.01.004

Haynes, A., Naylor, L. H., Carter, H. H., Spence, A. L., Robey, E., Cox, K. L., ... Green, D. J. (2020). Land-walking vs. water-walking interventions in older adults: Effects on aerobic fitness. Journal of Sport and Health Science, 9(3), 274-282. https://doi.org/10.1016/j.jshs.2019.11.005

He, W., Goodkind, D., \& Kowal, P. (2016). An Aging World: 2015 International Population Reports. Aging, (March), 165.

Hill, J. M., Zalos, G., Halcox, J. P. J., Schenke, W. H., Waclawiw, M. A., Quyyumi, A. A., \& Finkel, T. (2003). Circulating Endothelial Progenitor Cells, Vascular Function, and Cardiovascular Risk. Obstetrical \& Gynecological Survey, 58(7), 467-468. https://doi.org/10.1097/01.ogx.0000074096.62998.d7

Hill, M. D., Gibson, A. M., Wagerman, S. A., Flores, E. D., \& Kelly, L. A. (2019). The effects of aerobic and resistance exercise on state anxiety and cognitive function. Science and Sports, 34(4), 216-221. https://doi.org/10.1016/j.scispo.2018.09.004

Hooshmand-Moghadam, B., Eskandari, M., Golestani, F., Rezae, S., Mahmoudi, N., \& Gaeini, A. A. (2020). The effect of 12-week resistance exercise training on serum levels of cellular aging process parameters in elderly men. Experimental Gerontology, 141(June), 111090. https://doi.org/10.1016/j.exger.2020.111090

Hötting, K., Holzschneider, K., Stenzel, A., Wolbers, T., \& Röder, B. (2013). Effects of a cognitive training on spatial learning and associated functional brain activations. $B M C$ Neuroscience, 14, 73. https://doi.org/10.1186/1471-2202-14-73

Hötting, K., Reich, B., Holzschneider, K., Kauschke, K., Schmidt, T., Reer, R., ... Röder, B. (2012a). Differential cognitive effects of cycling versus stretching/coordination training in middle-aged adults. Health Psychology: Official Journal of the Division of Health Psychology, American Psychological Association, 31(2), 145-155. https://doi.org/10.1037/a0025371

Hötting, K., Reich, B., Holzschneider, K., Kauschke, K., Schmidt, T., Reer, R., ... Röder, B. (2012b). Differential cognitive effects of cycling versus stretching/coordination training in middle-aged adults. Health Psychology, 31(2), 145-155. https://doi.org/10.1037/a0025371

Hough, J., Corney, R., Kouris, A., \& Gleeson, M. (2013). Salivary cortisol and testosterone responses to high-intensity cycling before and after an 11-day intensified training period. 
Journal of Sport Education (JOPE), 4 (1) 2021 - 73

Upik Rahmi ${ }^{1 *}$, Nova Sylviana ${ }^{2}$, Hanna Goenawan ${ }^{3}$, Setiawan ${ }^{4}$

Journal of Sports Sciences, 31(14), 1614-1623. https://doi.org/10.1080/02640414.2013.792952

Hyodo, K., Dan, I., Kyutoku, Y., Suwabe, K., Byun, K., Ochi, G., ... Soya, H. (2016). The association between aerobic fitness and cognitive function in older men mediated by frontal lateralization. NeuroImage, 291-300. https://doi.org/10.1016/j.neuroimage.2015.09.062

Ji, N., Zhao, W., Qian, H., Yan, X., Zong, R., Zhang, Y., \& Lao, K. (2019). Aerobic exercise promotes the expression of ERCC1 to prolong lifespan: A new possible mechanism. Medical Hypotheses, 122, 22-25. https://doi.org/10.1016/j.mehy.2018.10.012

Karp, A., Paillard-Borg, S., Wang, H. X., Silverstein, M., Winblad, B., \& Fratiglioni, L. (2006). Mental, physical and social components in leisure activities equally contribute to decrease dementia risk. Dementia and Geriatric Cognitive Disorders, 21(2), 65-73. https://doi.org/10.1159/000089919

Kraemer, W. J., Fragala, M. S., Watson, G., Volek, J. S., Rubin, M. R., French, D. N., ... Evans, D. S. (2008). Hormonal responses to a $160-\mathrm{km}$ race across frozen Alaska. British Journal of Sports Medicine, 42(2), 116-120. https://doi.org/10.1136/bjsm.2007.035535

Leyland, L. A., Spencer, B., Beale, N., Jones, T., \& van Reekum, C. M. (2019). The effect of cycling on cognitive function and well-being in older adults. PLOS ONE, 14(2), 1-17. https://doi.org/10.1371/journal.pone.0211779

Leyland, L., \& Spencer, I. (2019). Pengaruh bersepeda pada fungsi kognitif dan kesejahteraan pada orang dewasa yang lebih tua.1-17.

Maass, A., Düzel, S., Brigadski, T., Goerke, M., Becke, A., Sobieray, U., ... Düzel, E. (2016). Relationships of peripheral IGF-1, VEGF and BDNF levels to exercise-related changes in memory, hippocampal perfusion and volumes in older adults. NeuroImage, 131, 142-154. https://doi.org/10.1016/j.neuroimage.2015.10.084

Maeda, S., Tanabe, T., Miyauchi, T., Otsuki, T., Sugawara, J., Iemitsu, M., ... Matsuda, M. (2003). Aerobic exercise training reduces plasma endothelin-1 concentration in older women. Journal of Applied Physiology, 95(1), 336-341. https://doi.org/10.1152/japplphysiol.01016.2002

Miyake, A., Friedman, N. P., Emerson, M. J., Witzki, A. H., Howerter, A., \& Wager, T. D. (2000). The Unity and Diversity of Executive Functions and Their Contributions to Complex "Frontal Lobe" Tasks: A Latent Variable Analysis. Cognitive Psychology, 41(1), 49-100. https://doi.org/10.1006/cogp.1999.0734

Molanouri Shamsi, M., Najedi, S., Hassan, Z. M., Isanejad, A., \& Mahdavi, M. (2017). Short term exercise training enhances cell-mediated responses to HSV-1 vaccine in mice. Microbial Pathogenesis, 110, 457-463. https://doi.org/10.1016/j.micpath.2017.07.035

Navaratnarajah, A., \& Jackson, S. H. D. (2013). The physiology of ageing. Medicine (United Kingdom), 41(1), 5-8. https://doi.org/10.1016/j.mpmed.2012.10.009 
Nehra, S., Bhardwaj, V., Bansal, A., \& Saraswat, D. (2017). Combinatorial therapy of exercisepreconditioning and nanocurcumin formulation supplementation improves cardiac adaptation under hypobaric hypoxia. Journal of Basic and Clinical Physiology and Pharmacology, 28(5), 443-453. https://doi.org/10.1515/jbcpp-2016-0134

Palmowski, J., Reichel, T., Boßlau, T. K., \& Krüger, K. (2020). The effect of acute running and cycling exercise on T cell apoptosis in humans: A systematic review. Scandinavian Journal of Immunology, 91(2), 1-11. https://doi.org/10.1111/sji.12834

Pan, M. H., Lai, C. S., Tsai, M. L., Wu, J. C., \& Ho, C. T. (2012). Molecular mechanisms for antiaging by natural dietary compounds. Molecular Nutrition and Food Research, 56(1), 88115. https://doi.org/10.1002/mnfr.201100509

Patil, S. G., Patil, S. S., Aithala, M. R., \& Das, K. K. (2017). Comparison of yoga and walkingexercise on cardiac time intervals as a measure of cardiac function in elderly with increased pulse pressure. Indian Heart Journal, 69(4), 485-490. https://doi.org/https://doi.org/10.1016/j.ihj.2017.02.006

Pietrelli, A., Matković, L., Vacotto, M., Lopez-Costa, J. J., Basso, N., \& Brusco, A. (2018). Aerobic exercise upregulates the BDNF-Serotonin systems and improves the cognitive function in rats. Neurobiology of Learning and Memory, 155, 528-542. https://doi.org/10.1016/j.nlm.2018.05.007

Portney, L. G. (2020). Foundations of Clinical Research: Applications to Evidence-Based Practice. In Foundations of Clinical Research: Applications to Evidence-Based Practice, $4 e$. Retrieved from http://fadavispt.mhmedical.com/content.aspx?aid=1172486561

Pothier, K., Gagnon, C., Fraser, S. A., Lussier, M., Desjardins-Crépeau, L., Berryman, N., ... Bherer, L. (2018). A comparison of the impact of physical exercise, cognitive training and combined intervention on spontaneous walking speed in older adults. Aging Clinical and Experimental Research, 30(8), 921-925. https://doi.org/10.1007/s40520-017-0878-5

Raichlen, D. A., Bharadwaj, P. K., Nguyen, L. A., Franchetti, M. K., Zigman, E. K., Solorio, A. R., \& Alexander, G. E. (2020). Effects of simultaneous cognitive and aerobic exercise training on dual-task walking performance in healthy older adults: results from a pilot randomized controlled trial. BMC Geriatrics, 20(1), 83. https://doi.org/10.1186/s12877-020-1484-5

Rea, I. M. (2017). Towards ageing well: Use it or lose it: Exercise, epigenetics and cognition. Biogerontology, 18(4), 679-691. https://doi.org/10.1007/s10522-017-9719-3

Rodrigues-Krause, J., Farinha, J. B., Krause, M., \& Reischak-Oliveira, Á. (2016). Effects of dance interventions on cardiovascular risk with ageing: Systematic review and meta-analysis. Complementary Therapies in Medicine, 29, 16-28. https://doi.org/10.1016/j.ctim.2016.09.004

Rodrigues-Krause, J., Farinha, J. B., Ramis, T. R., Macedo, R. C. O., Boeno, F. P., dos Santos, G. C., ... Reischak-Oliveira, A. (2018). Effects of dancing compared to walking on cardiovascular risk and functional capacity of older women: A randomized controlled trial. Experimental 
Journal of Sport Education (JOPE), 4 (1) 2021 - 75

Upik Rahmi ${ }^{1 *}$, Nova Sylviana ${ }^{2}$, Hanna Goenawan ${ }^{3}$, Setiawan ${ }^{4}$

Gerontology, 114, 67-77. https://doi.org/https://doi.org/10.1016/j.exger.2018.10.015

Rodrigues, T. B., \& Ballesteros, P. (2007). Journal of Neuroscience Research 85:3244-3253 (2007). Journal of Neuroscience Research, 3253(April), 3244-3253. https://doi.org/10.1002/jnr

Ross, M., Ingram, L., Taylor, G., Malone, E., Simpson, R. J., West, D., \& Florida-James, G. (2018). Older men display elevated levels of senescence-associated exercise-responsive CD28null angiogenic T cells compared with younger men. Physiological Reports, 6(12), 1-11. https://doi.org/10.14814/phy2.13697

Sarikaya, B., Dursun, A. D., Taylan Deveden, E. Y., \& Pinar, L. (2017). Interleukin-6 and hepcidin expression changes in cardiac tissue of long-term trained and untrained rats after exhaustive exercise. Turkish Journal of Medical Sciences, 47(6), 1940-1946. https://doi.org/10.3906/sag-1703-73

Shaw, D. M., Merien, F., Braakhuis, A., \& Dulson, D. (2018). T-cells and their cytokine production: The anti-inflammatory and immunosuppressive effects of strenuous exercise. Cytokine, 104(October 2017), 136-142. https://doi.org/10.1016/j.cyto.2017.10.001

Silva, P., Lott, R., Wickrama, K. a S., Mota, J., \& Welk, G. (2011). . This article appears here in its accepted, peer-reviewed form ; it has not been copy edited, proofed, or formatted by the publisher . Psychosoci. International Journal of Sport Nutrition and Exercise Metabolism, $1-44$.

Skriver, K., Roig, M., Lundbye-Jensen, J., Pingel, J., Helge, J. W., Kiens, B., \& Nielsen, J. B. (2014). Acute exercise improves motor memory: exploring potential biomarkers. Neurobiology of Learning and Memory, 116, 46-58. https://doi.org/10.1016/j.nlm.2014.08.004

Tascón, L., Boccia, M., Piccardi, L., \& Cimadevilla, J. M. (2017). Differences in spatial memory recognition due to cognitive style. Frontiers in Pharmacology, 8(AUG), 1-7. https://doi.org/10.3389/fphar.2017.00550

Torbeyns, T., De Geus, B., Bailey, S., De Pauw, K., Decroix, L., Van Cutsem, J., \& Meeusen, R. (2016). Cycling on a bike desk positively influences cognitive performance. PLoS ONE, 11(11), 1-14. https://doi.org/10.1371/journal.pone.0165510

Turner, J. E., \& Brum, P. C. (2017). Does Regular Exercise Counter T Cell Immunosenescence Reducing the Risk of Developing Cancer and Promoting Successful Treatment of Malignancies? Oxidative Medicine and Cellular Longevity, 2017. https://doi.org/10.1155/2017/4234765

Vasa, M., Fichtlscherer, S., Aicher, A., Adler, K., Urbich, C., Martin, H., ... Dimmeler, S. (2001). Number and migratory activity of circulating endothelial progenitor cells inversely correlate with risk factors for coronary artery disease. Circulation Research, 89(1), 1-8. https://doi.org/10.1161/hh1301.093953

Vingren, J. L., Budnar, R. G., McKenzie, A. L., Duplanty, A. A., Luk, H. Y., Levitt, D. E., \& 
Armstrong, L. E. (2016). The acute testosterone, growth hormone, cortisol and interleukin-6 response to $164-\mathrm{km}$ road cycling in a hot environment. Journal of Sports Sciences, 34(8), 694-699. https://doi.org/10.1080/02640414.2015.1068440

Wallace, R. G., Twomey, L. C., Custaud, M. A., Turner, J. D., Moyna, N., Cummins, P. M., \& Murphy, R. P. (2018). The role of epigenetics in cardiovascular health and ageing: A focus on physical activity and nutrition. Mechanisms of Ageing and Development, 174, 76-85. https://doi.org/10.1016/j.mad.2017.11.013

Weiss, L. R., Venezia, A. C., \& Smith, J. C. (2019). A single bout of hard RPE-based cycling exercise increases salivary alpha-amylase. Physiology and Behavior, 208(May), 112555. https://doi.org/10.1016/j.physbeh.2019.05.016

Whiteman, A. S., Young, D. E., He, X., Chen, T. C., Wagenaar, R. C., Stern, C. E., \& Schon, K. (2014). Interaction between serum BDNF and aerobic fitness predicts recognition memory in healthy young adults. Behavioural Brain Research, 259, 302-312. https://doi.org/10.1016/j.bbr.2013.11.023

Woost, L., Bazin, P. L., Taubert, M., Trampel, R., Tardif, C. L., Garthe, A., ... Klein, T. A. (2018). Physical Exercise and Spatial Training: A Longitudinal Study of Effects on Cognition, Growth Factors, and Hippocampal Plasticity. Scientific Reports, 8(1), 1-13. https://doi.org/10.1038/s41598-018-19993-9

Yaffe, K., Fiocco, A. J., Lindquist, K., Vittinghoff, E., Simonsick, E. M., Newman, A. B., ... Harris, T. B. (2009). Predictors of maintaining cognitive function in older adults: The Health $A B C$ Study. Neurology, 72(23), 2029-2035. https://doi.org/10.1212/WNL.0b013e3181a92c36

Yamazaki, Y., Yamashiro, K., Onishi, H., Otsuru, N., Kojima, S., Saito, K., \& Sato, D. (2020). Modulation of inhibitory function in the primary somatosensory cortex and temporal discrimination threshold induced by acute aerobic exercise. Behavioural Brain Research, 377(September 2019), 112253. https://doi.org/10.1016/j.bbr.2019.112253 